\title{
Determinants of Bank Deposits in Ghana: Does Interest Rate Liberalization Matters?
}

\author{
Eric Kofi Boadi ${ }^{1,2 *}$, Yao Li1 ${ }^{1}$, Victor Curtis Lartey ${ }^{1,2}$ \\ ${ }^{1}$ School of Management and Economics, University of Electronic Science \& Technology of China (UESTC), \\ Chengdu, China \\ ${ }^{2}$ Faculty of Business and Management Studies, Koforidua Polytechnic, Koforidua, Ghana \\ Email: boadikofieric@gmail.com
}

Received 24 August 2015; accepted 20 September 2015; published 23 September 2015

Copyright @ 2015 by authors and Scientific Research Publishing Inc.

This work is licensed under the Creative Commons Attribution International License (CC BY). http://creativecommons.org/licenses/by/4.0/

(c) (i) Open Access

\section{Abstract}

This research paper examines the effect of interest rate liberalization on bank deposits in a developing country Ghana. A deposit function model was specified with long term deposit as the main dependent variable with real savings rate, real treasury bill rate, exchange rate movement and gross domestic product as independent variables while controlling for inflation. Ordinary Least Squares (OLS) method was used to estimate the specified model which covered seasonally adjusted quarterly data drawn from Bank of Ghana and Ghana Statistical Service. The data were input into a spreadsheet and exported into Econometric View 7 which was used for processing the data. The results of the study revealed that the interest rate liberalization and gross domestic product jointly accounted for about $78 \%$ of the variation in the level of bank savings deposits in Ghana. The study has also shown that the liberalization of the interest rates has made it attractive for people with idle funds to save with financial institutions especially the banks. It also revealed a negative relationship between real savings rate and the real treasury bill rate expected in a high inflationary environment. All the independent variables were significant. It is therefore recommended that the Bank of Ghana remains resilience on interest rate liberalization so that surplus funds can be made available for investors and also to reduce the level of inflation in Ghana.

\section{Keywords}

Bank Deposits, Real Savings Rates, Exchange Rate Movements, Real Treasury Bill Rate and Gross Domestic Product

\footnotetext{
${ }^{*}$ Corresponding author.
} 


\section{Introduction}

Undoubtedly, deposits are the heart of financial institutions like banks [1]. Financial systems have been recognized to play an imperative role in economic development. One of such important factors in financial systems that account for growth in a country's economy is bank deposits [2]. By taking deposits, financial institutions such as banks put to rights wishes of small savers for high liquidity and low risk with the needs of investors through reconciliation [3]. Deposits are subject to numerous conditions; arguably, the most imperative and observable one is the rate the bank pays over the amount of savings. Deposit may be important for both developed and developing countries such that it helps depositors to earn on their funds which they have no immediate use for. It also creates a platform for banks to channel such funds to businesses and individuals who have urgent use of such funds. The total volumes of deposit distribution among individual banks and other financial sectors such as insurance are normally determined by market forces [4]. What basically fuel customers of banks to deposit money in banks in Ghana is the centre of this research. However, of much interest to our research is the area whether interest rate liberalization is a determinant of bank deposits compared to other empirically identified areas of interest by other researchers as reviewed in the study [5] [6]. The study's principal objective is to determine the volatility of interest rate liberalization and gross domestic product on Banks Deposit.

We hold the opinion that good interest rate liberalization promotes the sharing and efficiency in investment when there exists improved determination of capital and risks associated to bank deposits. In addition, we believe that an increase in bank deposits has the likelihood of improving Gross Domestic Product. Practically the study seeks to guide policy makers to maintain realistic interest rates that can attract idle funds into the banking system to be used by prospective investors by answering the questions; how has the interest rate liberalization in Ghana affected bank deposits? And what are its contributions to economic growth in Ghana? Hypothetically it will establish whether or not interest rate liberalization has no statistical significant implication on bank deposits in Ghana.

This study was limited to a developing country called Ghana in West Africa. With a population of 24,658,823 in 2010, a 30.4\% increase within the decade in 2010 as revealed by the Ghana Statistical Service (GSS) report. As at $31^{\text {st }}$ December, 2013 Ghana inflation rate was 13.8\%, Industry Producer Inflation of 23.3\%, Consumer Price index of 121.2 and Producer Price Index of 364.7 all as at January 2014, respectively (GSS).

Again, based on literature reviewed the conceptual framework below was deduced:

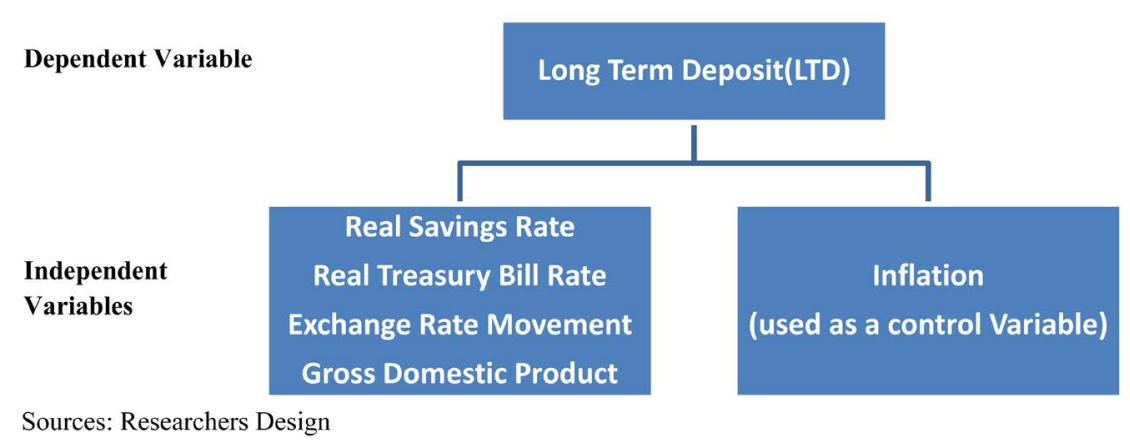

The study is organized into five parts. The first part as noted early introduces the relevance of the studies, and this is followed by literature review with theories and some perspectives on some empirical works. The third part looks at the methodology of the study, after which the fourth section presents and discusses the empirical results and lastly the fifth section concludes the study with suggestions.

\section{Review of Related Literature}

\subsection{Review of Theories}

In this review, some major theories were of utmost necessity. These theoretical evidences were reviewed with empirical considerations either supporting or refuting their basis.

Firstly, market concentrated effects on deposit rates offers evidences from structure-conduct-performance hypothesis theory. This theory suggests a concentrated structure will lead to less competitive conduct and less 
competitive performance. [7] supported lower deposit interest rates due to factors such as higher profit by banks at the expense of consumer welfare. In similar sphere [8] find less favorable pricing to consumers due to the fact that banks may find it easier to collude. In respect to competitive imperfection, [9] indicated competitive imperfections in markets leads to lower deposits rate. From the perspective of concentrated market, [10] suggests higher profit rates, higher loan interest rates, lower deposit rate. [11] using Herfindahl index reveals that on average, there is lower deposit rate in more concentrated market. [12] established that concentrated markets banks are slower to raise interest rates on deposits in reaction to increasing market interest rates but are faster to decrease them in reaction to failing market interest rates (p. 944). This was confirmed by [8].

With respect to the above hypothesis, we hold the view that if business is all about maximization of profits as appears in financial literatures then tactics adopted by banks to increase loan interest rate and to react to market failings and others all to the demerits of their consumers stands a greater probability of reducing deposits. Banks which value the profit objective must offer better welfare packages to attract more deposits and the higher the number of customers deposit even with a small amount, the rapid increase would be the bank deposit all other this being equal.

Secondly, closely related to the above is the relative-market-power hypothesis with the theory that only firms (Banks) with large market shares and well-differentiated products are able to exert market power in pricing deposits with the effect of low deposit rates in large market share [9] [13]. This to us is true in the contest of the above, since its relative power pricing in a dominated market environment where a bank has constantly achieved a sustainable competitive advantage.

Another contra hypothesis which is proxy on overall efficiency worth mentioning is the efficient-structurehypothesis theory. It argues that a concentrated structure increases the overall efficiency of the banking sector, hence banks price their deposits more competitively and the end effect is higher deposit rates in more concentrated markets [8] [9]. Also a researched [14] investigated bank deposit products in the Spanish market. They discovered that, if banks increases in a market, both deposit interest rates and dispersion in the interest rates also tend to increase. We support such a premise because it's conditioned on certain factors.

The above evidence among the theories is an evidence that numerous factors account for bank deposit, hence the current research in the Ghanaian banking sector is of optimum interest. In our view, irrespective of the nature of market forces, if there exist excessive demand of bank loans, to some extent it has the propensity to influence banks to develop a mechanism to encourage bank deposits though macroeconomic parameters may have a role. One of such factors is the increase in deposit rate, hence the need to liberalize interest rate from the perspective of the regulator though it may have its own shortfalls. Interest rate liberalization may impact on interest rate systems. However, the experience of many countries with regards to interest rate liberalization has been mixed [15]. Whether interest rate liberalization does indeed impact positively on financial deepening and economic growth and for that matter deposit, as postulated by the proponents of interest rate liberalization, it remains an issue of empirical reinvestigation in the Ghanaian banking environment.

\subsection{Empirical Review of Literature}

Previous empirical studies concentrated on Asia and Latin America, affording Sub-Saharan African (SSA) countries very little coverage. For instance, little evidence for the positive role of interest rate liberalization on savings was found and that financial liberilization led to capital flight [16]. Other researchers hold the view that firms try to oppose financial reforms that breed competition [17]. Again, according to [18] if competition among banks in newly deregulated financial sector is weak, there is the possibility that financial liberalization may result in lower real deposit rates rather than the anticipated movement toward modestly positive equilibrium levels.

Furthermore, empirical study [19] after surveying the market reforms from 1986 to 2003, confirmed that there has been negative impact of financial liberalization on the industrial sector in Nigeria. As far back, [20] tested the validity of the McKinnon and Shaw model for seven Asian countries. He concluded that the real rate of interest exerted a positive influence on the ratio of domestic savings to GNP; a 10\% increase of real rate of interest, all other things being equal, raise the ratio of savings to GNP by approximately $1.4 \%-2.1 \%$. His models were based on permanent income hypothesis. To us we hold similar view that income is a probable determinant of bank deposit, hence we proxy income based on the gross domestic product.

[5] for example, whilst examining the impact of financial liberalization on access to rural credit in a number 
of countries, it was found that, the impact of financial sector reforms on deposits as measured by bank deposits and M2 as a percentage of GDP, varies between countries. There was little change in financial depth in Madagascar, and a small decline in Malawi. Although Tanzania suffered a sharp contraction of financial depth in the second half of the 1980s, the country recovered almost half of the fall in the first half of the 1990s. In Uganda a small recovery was achieved in the first half of the 1990s after the collapse in financial depth in the 1980s, but the financial system remained very shallow. In Zambia, the reforms were unable to prevent a continued rapid decline in financial depth, which began in the first half of the 1980s. [21] also conducted a study on financial deepening, credit availability and the efficiency of investment in 17 African countries. His analysis uses three variants to test the aspect of financial deepening in these countries. The results of this study show that the real rate of interest turned out to be positive and significant in 12 out of the 17 countries in the sample. The variable was significant in Kenya, Ghana, Nigeria, Cameroon, Burundi, Rwanda, Sierra-Leon, Ethiopia, Niger, Zambia, Malawi, Cote divoire, and Mauritius. Although the real interest rate was positive in Tanzania, in Botswana and Lesotho it was not statistically significant. In other instances, lending at high interest rates has undermined economic growth by reducing firms' ability to service their debt, thereby weakening bank's balance sheet positions [22].

[23] studies on 12 Asian countries modelled Permanent Income Hypothesis and tested it for real interest rate responsiveness of savings. He estimated the model using 2 alternative definitions of savings; aggregate national savings and private savings; [23] concluded that McKinnon and Shaw model were quite limited. The hypothesis was rejected in all but four cases namely Pakistan, Sri-Lanka, the Philippines and Thailand. In other cases, either the effect was negative or the real rate of interest has no effect.

[24] suggests that investment, through savings, will be positively correlated with below-equilibrium interest rates and negatively correlated with above-equilibrium rates; [25] find a negative relationship between real interest rates and investment; and [26] indicated that real interest rates have no significant impact on investment. In line with findings such as Gelb's, a number of empirical studies on investment in least-developed countries (LDCs) excluded interest rates from the regressions [27] [28].

[29] worked on a cross section of developing countries including Argentina, Brazil, Ghana and Malaysia. They rightly established the point that the prevailing levels of the interest rate in these developing countries have been sub-optimal. In particular, they have shown that real interest rate has been predominantly negative and this has adversely affected allocation of resources.

According to [30] the persistence of high interest rates spread has been a disturbing outcome of marketoriented reforms in some Latin American countries. In sub-Saharan Africa, during 1996-1999, deposit rates averaged 9 per cent in Tanzania, 22 per cent in Malawi, and 27 per cent in Zimbabwe. During the same period, spread between lending and deposit rates averaged 17 per cent, 19 per cent, and 14 per cent in Tanzania, Malawi, and Zimbabwe respectively.

The results [31] covering 64 developing countries over the period 1970-1993 indicated that, changes in real interest rates had no significant effect on private or national saving.

[32] using a panel of 41 Sub-Saharan African countries to investigate the effectiveness of public policies in stimulating private savings and investment. They found that policies that kept inflation low, reduced macroeconomic uncertainty, promoted financial development, and increased public saving led to higher national savings.

Another empirical study focusing on sub-Saharan Africa [32] reached the conclusion that, policies aimed at fostering macroeconomic stability (lower inflation and real interest and exchange rates variability) tend to promote private investment. A Study [33] used an extensive cross-country database to study the determinants of savings. Their analysis showed, in particular, that macroeconomic uncertainty (as measured by the variance of inflation as well as volatility in interest rates) had a positive effect on private saving rates.

A major financial sector programme initiated in Ghana since the late 1980s, involved financial liberalization and institutional reforms. Under the financial reform, interest rates have been deregulated. This move was in part to encourage competition among the banks. The deregulation of the interest rate was also to conform to the new form of financial programming that Ghana was following under the Structural Adjustment Programme (SAP). Under the SAP, Ghana was using money supply as the nominal anchor. This implied that the price of money (the rate of interest) should be determined by market forces [34]-[38].

Theoretically, the word savings is widely used in economics, finance, statistics, accounting and commerce to denote that part of revenue which is yet to be used on present consumption [39]-[41]. From all the above, in our perspective when the excess of the above savings is deposited at bank then is called bank deposits.

From our point of view there appears also that, not much have be done in establishing if interest rate liberali- 
zation induces bank deposit. Whiles some interest have evolve on financial reforms as a savings determinants and are on the deposit rate, this therefore makes the debate still rife and hence the necessity of the current study.

Again from our perspective, enormous perception without or with little empirical evidence per our knowledge in Ghana holds the position that even though interest rates might not significantly affect the savings rate, they do influence economic growth through their effect on financial deepening.

The inconclusive nature of the previous empirical studies on the efficacy of financial liberalization in many developing countries has led to a renewed interest in the effect of interest rate liberalization on savings sparking current research in Ghana [42] [43]. In Ghana a study by [42] on financial liberalization and banking sector performance reveal that financial liberalization has helped in the declines of interest rates which they hypothesized using Herfindahl-Hirscham Index (HHI) of structured-Conduct-Performance (SCP) model. Recent study [43] closely related to our study, concluded that, until foreign and unproductive assets like cash and gold are channelled through the banking sector, financial liberalization will not have significant impacts on private investment in developing countries citing Ghana. According to his study it has a greater potential to stifled economic growth in developing countries. Apart from the above cited, little can be said on determinants of bank deposits particularly in Ghana as their study failed to establish that, reduction in interest rates due to financial liberalizations induce bank deposits and its level of sensitivity to bank deposits. Hence the current study on determinants of bank deposits; does interest rate liberalization matter?

Interest rate liberalization can be characterized as part of the broader financial liberalization. Financial liberalization may be defined as the process of delegating to the market the authority to determine who receives and grants credit, and at what price. Full financial liberalization involves six main dimensions: the deregulation of interest rates, the elimination of credit controls, free entry into the banking sector, central bank autonomy, private ownership of banks, and liberalization of international capital flows [44].

In Ghana, after the Structural Adjustment Programme, one major national policy was to promote economy growth through low interest rate to increase the level of investment, improve the allocation of investment among various sectors and finally to keep financial costs down so as to avoid the possible inflationary effects of interest rate liberalization. This policy was in line with Keynesian school of thought that with low interest rates more investment could take place for output to increase so that saving also increases. This mechanism works because the latter is a residual of output, especially, in a developing country where incomes and investments are low.

As researchers, we hold the opinion that, banks should be gingered to promote savings in a country and that liberalizing interest rate is in its right direction but we need to unveil whether such liberalization have fulfilled its purpose. We believe the objective of Bank of Ghana to set the minimum rates for deposits and placed ceilings on lending rates to serve as an incentive to attain higher levels of investment is in the right direction. The question we seek to unruffled is, how has interest rate liberalization contributed to bank deposit in a country like Ghana.

\section{Methodology}

This part specifies the empirics' model considered for the investigation. It present the data source and the methods used to analyze the data. It is followed with the model specifications of variables based on the conceptual framework employed for the study.

\subsection{Data Issues}

The method used is quantitative as well as exploratory and it describes variables and examines relationships among variables and to determine the effect of interactions between variables [45].

The study used secondary data on deposits, interest rates and inflation based on the consumer price index (year-on-year) obtained from Bank of Ghana (BOG) and Ghana Statistical Service website (GSS) respectively. The analysis covers adjusted quarterly data from periods 1991 to 2012 to be seasonal. Research papers from the International Monetary Fund (IMF) publications, the World Bank publications and other scholarly peer reviewed journals were also considered.

\subsection{Model Specification and Measurement of Variables}

This paper determines the determinants of bank deposits with peculiar attention on interest rate liberilization. The baseline of our model on previous literature studied [46] [47] we specify the panel model below: 


$$
L T D_{t}=\beta_{0}+\beta_{1} R S D_{t}+\beta_{2} R T B I L L_{t}+\beta_{3} R D E X R A T E+\beta_{4} G D P+\beta_{5} D U M M Y+\varepsilon_{t}
$$

where:

LTD: is the long term deposits defined as the sum of savings and time deposits: measured in billion Ghana Cedi's (certificate of deposit).

$R S D$ : is the real savings deposits rate measured in percent. Defined as $\ln \left(\frac{s d}{p}\right)$ where $\ln$ is the natural $\log$ and $p$ is the rate of inflation. We expect a positive outcome that an increase in real savings rate increases deposits all other things remaining the same.

RTBILL: is the real treasury bill rate. Defined as $\ln \left(\frac{\text { tbill rate }}{p}\right)$ where T-bill rate is the interest rate on the 91-day treasury bill rate. We expect a decrease in real treasury bill rate to account for a decline in treasury bill and an increase in bank deposits.

RDEXRATE: This represents the movement in exchange rate. Particularly it accounts for depreciation of the exchange rate relative to the rate of inflation. Defined as $\ln \left(\frac{\text { ex rate depreciation }}{p}\right)$ where ex rate depreciation is the yearly rate of depreciation of the exchange rate and p again rate of inflation.

GDP: is the Gross Domestic Product of the country Ghana, defined in terms of income.

DUMMY: is dummy variable to capture the effect of interest rate liberalization. It takes on the value of zero for the period prior to interest rate liberalization and one during the post liberalization period.

\subsection{Estimations Issues}

This study adopts the Ordinary Least Squares Techniques (OLS) estimation. The time series variables were tested for unit root and were found not to be stationary hence they were differenced to ensure the mean reverting properties of the variables [48]. This is very necessary because macro series are most likely to be non-stationary and thus yield spurious regression results if used in their levels.

We begin by establishing the trends in the time series variables.

In Panel 1 below, we plot the graphs of all the variables under consideration. The plots clearly show that all

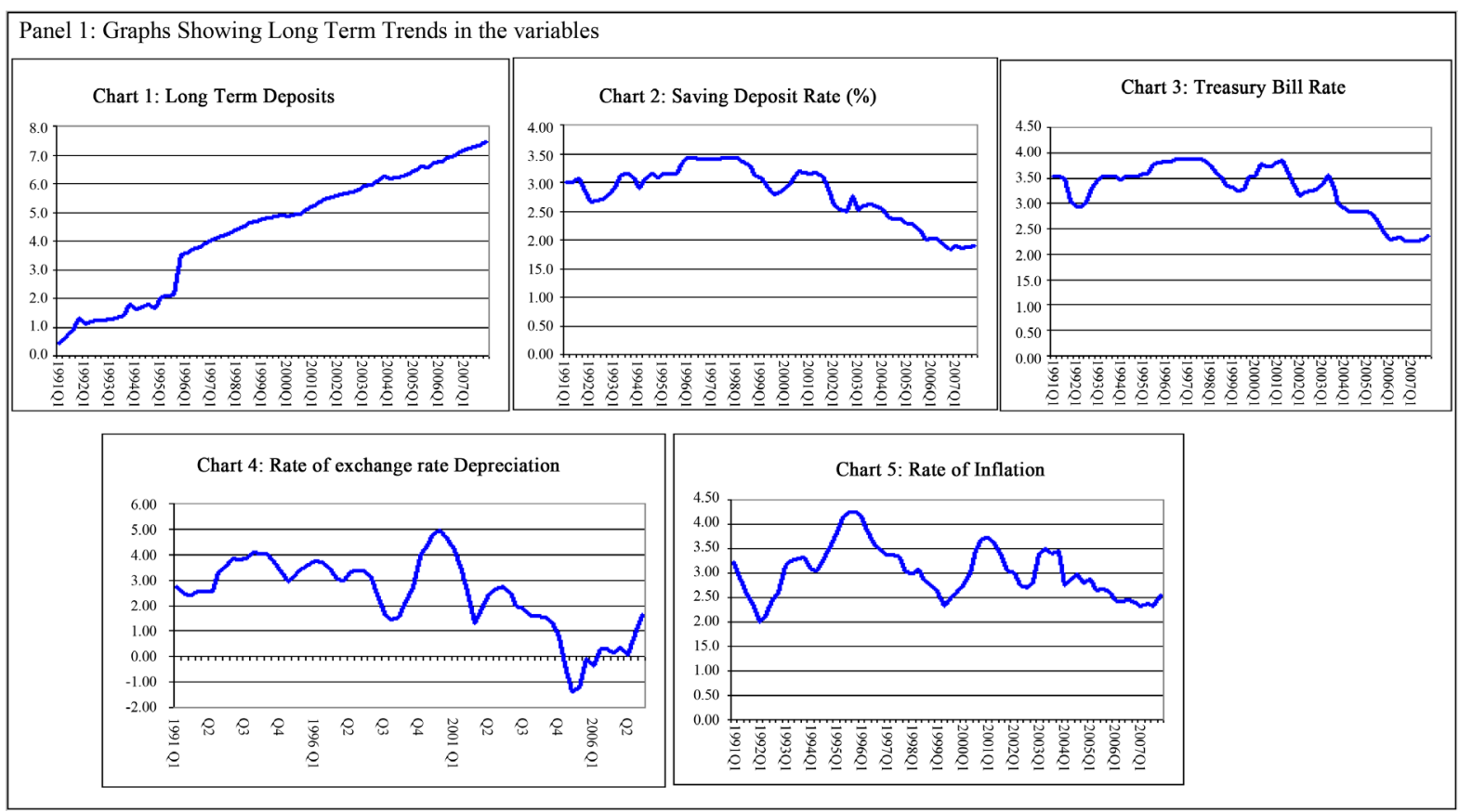

Panel 1. Trends in the time series variables. 
the variables; Long Term deposits, Savings rate, Treasury bill rate, rate of depreciation of the currency all exhibit tendencies of containing trends. There is no reversion of the variables under consideration to a mean value.

In Panel 2 we demonstrate how the variables behave after first difference.

We observed that after the first difference of the series all variables tend to oscillate around a mean value indicating some element of stability in the series. A confirmation of this fact was tested using the Augmented Dickey Fuller (ADF) Test. The results of the ADF tests did confirm that the series are all integrated of order 1 an indicative that OLS can be used in estimating the relationship specified in the equation. In order to interpret the coefficients of the results as elasticity, all the variables were entered in logarithmic values as indicated under model specification. The frequency of the data used was seasonal quarterly and covered the period 1994:q2 to 2012:q4.

\section{Empirical Results and Econometric Analysis}

Under this section we present the empirical results and econometric analysis based on the conceptual framework development to explain the relevance of interest rate and gross domestic product to bank deposits.

\subsection{Empirical Results}

This part of the study discusses the empirical results of our regression.

Regression table:

\begin{tabular}{ccc}
\hline Variable & Coefficient & Prob. \\
\hline C & 0.212021 & 0.3625 \\
RSD (-1) & -2.312242 & $0.0003^{*}$ \\
RTBILL (-1) & 2.573284 & $0.0004^{*}$ \\
REXDEP (-1) & -1.23145 & $0.0001^{*}$ \\
GDP (-1) & 32.32531 & $0.0002^{*}$ \\
DUM2003 & 2.14124 & $0.0464^{* *}$ \\
\hline
\end{tabular}

Significant level ${ }^{*} 1 \%$ and ${ }^{* *} 5 \%$. R-square: 0.7758 . Adjusted $R^{2}: 0.7276$. F-statistics: 7.5605 . Prob (F-statistics): 0.0000.

Included observations 75 after seasonal adjustments.

The regression equation:

$$
L T D=0.21-2.31 \beta_{1}+2.57 \beta_{2}-1.23 \beta_{3}+32.33 \beta_{4}+2.14 \beta_{5}
$$

\subsection{Econometric Analysis of the Empirical Results}

In determining the impact of interest rate liberilization on bank deposits the following observations were made from the statistics derived from our regression results.

Firstly, we observed that the Real Savings rate, the Treasury bill rate, the volatility in exchange rate movement, and gross domestic product in Ghana accounts of about 78\% of the variations in the level of Deposits. This suggests less than 25\% of factors that accounts for deposits in Ghana has not been captured through this process. Secondly, all the variables apart from the dummy which was significant at $5 \%$, the remaining were statistically significant at $1 \%$ and this indicates that the choice of variables were highly appropriate. The significant of the F-statistics future attests that all the independent variables jointly explain the dependent variable.

We fail to reject the null hypothesis that, interest rate liberilization has no statistical significant since the pvalue of the dummy is less than $5 \%$.

Notwithstanding, the predicted signs on the real savings rate and the real treasury bill rate deviated from what we expected. For instance while we expected a positive increase in real savings rate (RSD) to deposits, this turned out to be negative though it was statistically significant with it $\mathrm{p}$-value $0.003<$ alpha value of 0.05 . Also, the real treasury bill rate (RTBILL) was statistically significant. The outcome was not anticipated. We expected a decrease in real treasury bill rate to propel a greater likelihood of declining risk free investment proxy by treasurer bill. The results turned to be the inverse. We confirm one marginal effect that, a decrease in real treasury 


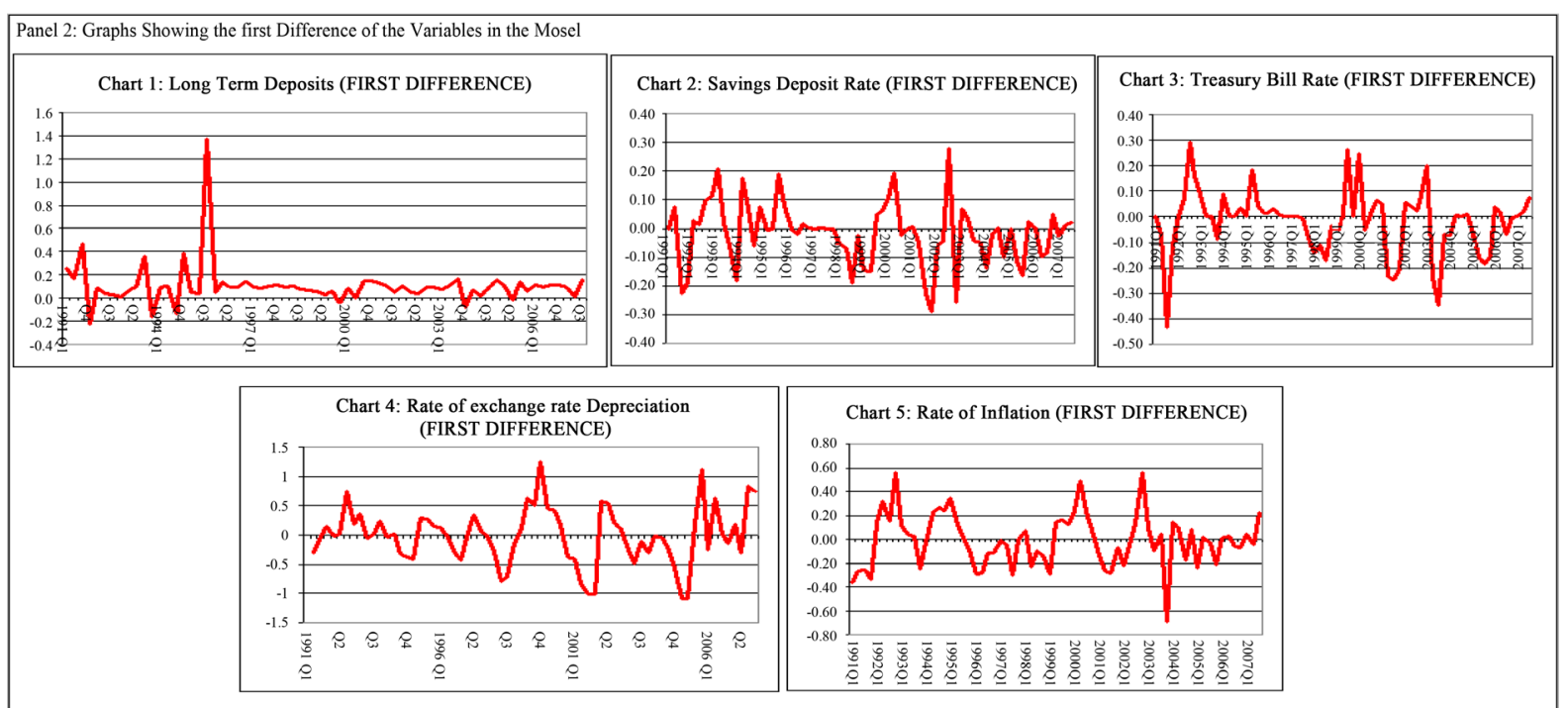

Panel 2. Graphs showing the first difference of the variables in the model.

bill rate increases the demand for treasury bill by about 2.5. This indicates customer's greater desire (demand) for risk free investments irrespective of the decrease in rate of interest. In our view a "flight to safety" usually resulting from default risk or liquidity risk in other possible financial markets makes their client to shift to treasury bills. This is consistent with high inflationary environment where real interest rates are usually negative and a decrease in real treasury rate results in an increase in the demand of treasury bills. This study support [49] argument that Treasury bill rates typically falls in economic recession period but rise in periods of business expansion. The Gross domestic product which measure economic growth provided enough evidence of such a situation.

In respect to exchange rate, the results were consistent with our expectations. The results show a marginal effect of depreciation in the level of the currency relative to the rate of inflation could hypothetically cause the level of deposits to decline by about 1.23. This supports the old axiom by economic agents that, resources are likely to be shifted into foreign exchange market, when the rate of depreciation is expected to surpass the rate of inflation.

Again we find that, an increase in the savings rate for instance decrease the level of savings by about 2.31 . One credible reason is the unattractive saving rate by the banks. In Ghana what attracts money deposits is promotional packages of banks. Banks usually entice customers to increase or maintain a particular balance over a given period to qualify them for a raffle which takes diverse forms, like cash rewards, educational packages, travelling and et cetera.

The economic growth based on a macroeconomic indicator variable Gross Domestic Product (GDP) defined as GDP income proxy demonstrated a strong existence. We find a marginal increase has the likelihood of increasing the bank deposits by 32. It indicates that once the economic grows there is a greater likelihood of an increase in Bank deposits. This shows that in Ghana a quite number of the working population falls in the public sector employment.

The dummy was relevant in the third quarter of 2003 and the second quarter of 2012. We are reliably aware that in 2003, a huge wage settlement of about 30 percent was executed by the Ministry of Finance and this potentially accounted for the huge increase in deposits observed during that period. This was a year to the 2004 elections. Similarly, in the second quarter of 2012 the payment of Single Span Salary Arrears by government to its public sector workers under the uniform salary structure based on equal work equal pay with same equivalent condition of service classifications increased bank deposits astronomically. In our candid view, this was a politically motivated decision by the government especially where it was barely or even less than six months to the 2012 elections in Ghana. This is expected in most developing countries particularly in Africa as governments seek another term of office. Such increases have no permanence nature and therefore are not reliable deposits.

From other empirically studies, our study is consistent with the positive relationship between interest rate and savings studies conducted by [20] on the validity of the McKinnon and Shaw model for seven Asian countries 
and by [21] on financial deepening, credit availability and the efficiency of investment in 17 African countries and finally with the studies conducted by [50]. But it is inconsistent with the studies conducted by [23] on 12 Asian countries, [25], and by [31] covering 64 developing countries over the period 1970-1993.

From this study, we also made the following major observations:

Of the three deposit mobilization products studied, the time deposit was the most interest rate sensitive product. Volumes of deposit in this category mainly rise and fall with changes in interest rate. Corporate account holders in their consciousness of returns on investment allow banks to maintain interest rate as close as possible to the Treasury bill rate. The unusually low volume of time deposit may be as the result of deteriorating economic conditions. Ghanaian private sector is quite insensitive to changes in interest rates.

The individual saver, more or less, operates savings account as part of his "fixed" assets to be bequeathed unto the next-of-kin. The small scale proprietor would also put the enterprise's funds in demand deposit to enable him attain bank loan and therefore is least interested in the return on the investment.

It is interesting therefore to note that many educated middle-income level individuals do not maintain bank account of the categories studied. The Treasury bill, which apart from being risk-free, is also inflation-indexed, continues to be the most attractive instrument on the Ghanaian market for this group of individuals.

\section{Conclusions and Policy Implications}

The study accounts for $78 \%$ of the linkage between interest rate volatility, gross domestic product and the level of deposit mobilization of the Ghanaian banking system.

Specifically, we conclude that:

1) Both interest rate liberalization and gross domestic product are important determinants of bank deposits though other factors may also counts.

2) Gross domestic product proxy by income was a major significant factor of bank deposits determinants with a high coefficient value.

3) High inflation and deteriorating foreign exchange rate could keep interest rates high without necessarily impacting on the level of savings.

4) The interest rate product of bank customers is influence by:

a) Customers conscious of the investment risks and returns;

b) Customers aim of earning returns on bank deposits;

c) Macroeconomic conditions prevailing in the country.

In respect to policy measures the regulatory supervisors of most developing countries like Ghana must pay attention to:

a) The education of citizens through communication medium on personal finance;

b) The establishing of a secondary market for treasury bills and other financial product to encourage competition;

c) Improve macroeconomic measures particularly inflation which highly affects interest rate;

d) Encourage competition in the banking sector in Ghana as a measure of checking interest rate;

e) Rural community banks should be encourage to introduce innovative financial products as means of encouraging rural dwellers to deposit money at bank instead of keeping it under their "beds".

Finally, government and other stakeholders in developing countries which practice democratic election should pay attention to elections years to ensure that both pre and post democratic elections have low profile of fear and panic to enhance developing countries economic activities, since periods close to election and just after election makes citizens skeptical on their bank deposits.

\section{References}

[1] Fama, E.F. (1980) Banking in the Theory of Finance. Journal of Monetary Economics, 6, 39-57. http://dx.doi.org/10.1016/0304-3932(80)90017-3

[2] King, R. and Levine, R.G. (1993) Finance, Entrepreneurship and Growth: Theory and Evidence. Journal of Monetary Economics, 32, 513-542. http://dx.doi.org/10.1016/0304-3932(93)90028-E

[3] Maes, T. and Timmermans, K. (2000) Measuring the Interest Rate Risk of Belgian Regulated Savings Deposits.

[4] Cohen, B.C. and Kaufman, G.G. (1965) Factors Determining Bank Deposit Growth by State: An Empirical Analysis. Journal of Finance, 20, 59-70. 
[5] Mosley, P. (1999) Micro-Macro Linkages in Financial Markets: The Impact of Financial Liberalization on Access to Rural Credit in Four African Countries. Journal of International Development, 11, 367-384. http://dx.doi.org/10.1002/(SICI)1099-1328(199905/06)11:3<367::AID-JID589>3.0.CO;2-W

[6] Pattillo, C. (1998) Investment, Uncertainty, and Irreversibility in Ghana. Staff Papers-International Monetary Fund, 45, 522. http://dx.doi.org/10.2307/3867414

[7] Shaffer, S. (1994) Bank Competition in Concentrated Markets. Business Review_Federal Reserve Bank of Philadelphia, 3-16.

[8] Gropp, J., Sorensen, R. and Lichtenberger, C.K. (2007) The Dynamics of Bank Spread and Financial Structure. No 714, Working Paper Series from European Central Bank.

[9] Berger, A.N. (1995) The Profit-Structure Relationship in Banking-Tests of Market-Power and Efficient-Structure Hypotheses. Journal of Money Credit and Banking, 27, 404-431. http://dx.doi.org/10.2307/2077876

[10] Tokle, J.G. and Tokle, R.J. (2000) The Influence of Credit Union and Savings and Loan Competition on Bank Deposit Rates in Idaho and Montana. Review of Industrial Organization, 17, 427-439. http://dx.doi.org/10.1023/A:1007894216526

[11] Hutchinson, D.E. (1995) Retail Bank Deposit Pricing: An Intertemporal Asset Pricing Approach. Journal of Money, Credit and Banking, 27, 217-231. http://dx.doi.org/10.2307/2077860

[12] Neumark, D. and Sharpe, S.A. (1992) Market Structure and the Nature of Price Rigidity: Evidence from the Market for Consumer Deposits. The Quarterly Journal of Economics, 107, 657-680. http://dx.doi.org/10.2307/2118485

[13] De Graeve, F., De Jonghe, O. and Vander Vennet, R. (2007) Competition, Transmission and Banking Pricing Policies: Evidence from Belgian Loan and Deposit Markets. Journal of Banking \& Finance, 31, 259-278. http://dx.doi.org/10.1016/j.jbankfin.2006.03.003

[14] Martin-Oliver, A., Salas-Fumas, V. and Saurina, J. (2008) Search Cost and Price Dispersion in Vertically Related Markets: The Case of Banks Loans and Deposits. Review of Industrial Organization, 33, 297-323. http://dx.doi.org/10.1007/s11151-008-9192-x

[15] Onwumere, J.U.J. and Okore Amah Okore, I.G.I. (2012) The Impact of Interest Rate Liberalization on Savings and Investment: Evidence from Nigeria. Research Journal of Finance and Accounting, 3, 130-136.

[16] Yalta, A.Y. and Yalta, A.T. (2012) Does Financial Liberalization Decrease Capital Flight? A Panel Causality Analysis. International Review of Economics \& Finance, 22, 92-100. http://dx.doi.org/10.1016/j.iref.2011.09.003

[17] Akinlo, A.E. and Egbetunde, T. (2010) Financial Development and Economic Growth: The Experience of 10 SubSaharan African Countries Revisited. The Review of Finance and Banking, 2, 17-28.

[18] Pill, H. and Pradhan, M. (1997) Financial Liberalization in Africa and Asia. Finance \& Development, 34, 7-10.

[19] Nowak-Lehmann, F. (2003) Trade Policy and its Impact on Economic Growth: The Chilean Experience in the Period of 1960 to 1998. Applied Econometrics and International Development, 3, 25-53.

[20] Fry, M.F. (1978) Money and Capital or Financial Depeening in Economic Development. Journal of Money, Credit and Banking, 10, 464-475. http://dx.doi.org/10.2307/1991576

[21] Ikhide, S.I. (1993) Positive Interest Rates: Financial Deepening and the Mobilisation of Savings in Africa. Development Policy Review, 11, 367-382. http://dx.doi.org/10.1111/j.1467-7679.1993.tb00047.x

[22] Nkusu, M.M. (2003) Interest Rates, Credit Rationing, and Investment in Developing Countries, No. 3-63. International Monetary Fund.

[23] Gupta, K.L. (1987) Aggregate Savings, Financial Intermediation, and Interest Rate. The Review of Economics and Statistics, 69, 303-311. http://dx.doi.org/10.2307/1927238

[24] Rittenberg, L. (1991) Investment Spending and Interest Rate Policy: The Case of Financial Liberalisation in Turkey. The Journal of Development Studies, 27, 151-167. http://dx.doi.org/10.1080/00220389108422190

[25] Greene, J. and Villanueva, D. (1991) Private Investment in Developing Countries: An Empirical Analysis. IMF Staff Papers, 38, 33-58. http://dx.doi.org/10.2307/3867034

[26] Gelb, A.H. (1989) Financial Policies, Growth, and Efficiency.

[27] Cardoso, E. (1993) Private Investment in Lantin America. Economic Development and Cultural Change, 41, 833-848. http://dx.doi.org/10.1086/452050

[28] Ramirez, M.D. (2000) The Impact of Public Investment on Private Investment Spending in Latin America: 1980-95. Atlantic Economic Journal, 28, 210-225. http://dx.doi.org/10.1007/bf02298362

[29] Lanyi, A. and Saracoglu, R. (1983) Interest Rate Policies in Developing Countries. Occasional Paper 22, Washington DC, International Monetary Fund.

[30] Brock, P.L. and Suarez, L.R. (2000) Understanding the Behavior of Bank Spreads in Latin America. Journal of De- 
velopment Economics, 63, 113-134. http://dx.doi.org/10.1016/S0304-3878(00)00102-4

[31] Masson, P.R., Bayoumi, T. and Samiei, H. (1995) International Evidence on the Determinants of Private Saving.

[32] Hadjimichael, M. and Ghura, D. (1995) Public Policies and Private Savings and Investment in Sub-Saharan Africa: An Empirical Investigation.

[33] Loayza, N., Schmidt-Hebbel, K. and Servén, L. (1999) What Drives Private Savings around the World? Central Bank of Chile. http://dx.doi.org/10.1596/1813-9450-2309

[34] Servén, L. (1997) Uncertaintainty, Instability, and Irreversible Investment: Theory, Evidence, and Lessons for Africa. World Bank Policy Research Paper No. 1722.

[35] Aizenman, J. and Marion, N.P. (1993) Policy Uncertainty, Persistence and Growth. Review of International Economics, 1, 145-163. http://dx.doi.org/10.1111/j.1467-9396.1993.tb00012.x

[36] McKinnon, R.I. (1973) Money and Capital in Economic Development. Brookings Institution Press, Washington DC.

[37] Khatkhate, D. (1991) The Central Bank’s Role in Financial Sector Development. In: Downes, P. and Vaez-Zadeh, R., Eds., The Evolving Role of Central Banks, International Monetary Fund, Washington DC, 16-29.

[38] Amonoo, E., Acquah, P.K. and Asmah, E.E. (2003) The Impact of Interest Rates on Demand for Credit and Loan Repayment by the Poor and SMEs in Ghana. IFLIP Research Paper 03-10, International Labor Organization.

[39] Smith, A.W. (1991) Understanding Economics. 2nd Edition, Macmillan/McGraw-Hill Company Inc., New York.

[40] Miller, D.D. and Van Hoose, R.L. (2007) Money, Banking and Financial Markets. South-Western Cengage Learning, Mason.

[41] Clayton, G.E. and Brown, J.E. (1983) Economics Principles and Practice. Charles E. Merill Publishing Company, Columbus.

[42] Adams, S. and Agbemade, J. (2012) Financial Liberalization and Banking Sector Performance in Ghana. African Journal of Business Management, 6, 11598-11608.

[43] Asare, E. (2013) The Impact of Financial Liberalization on Private Investment in Ghana. The International Journal of Business and Finance Research, 7, 77-90.

[44] Williamson, J. and Mahar, M. (1998) A Survey of Financial Liberalization. Princeton Essays in International Finance, No. 211

[45] Burns, N. and Grove, S. (2005) The Practice of Nursing Research: Conduct, Critique, and Utilization. 5th Edition, Elsevier Saunders, St. Louis.

[46] Gupta, K.L. (1984) Finance and Economic Growth in Developing Countries. Vol. 37, Taylor \& Francis, UK.

[47] Giovannini, A. (1985) Saving and the Real Interest Rate in LDCs. Journal of Development Economics, 18, $197-217$. http://dx.doi.org/10.1016/0304-3878(85)90054-9

[48] Hendry, D.F. (2000) Explaining Cointegration Analysis : Part I. Energy Journal, 21, 1-29. http://dx.doi.org/10.5547/ISSN0195-6574-EJ-Vol21-No1-1

[49] Rose, P.S. (1994) Money and Capital Markets. Irwin, Boost.

[50] Levine, R., Loayza, N. and Beck, T. (2000) Financial Intermediation and Growth: Causality and Causes. 